МІЖНАРОДНІ ЕКОНОМІЧНІ ВІДНОСИНИ

УДК 339.9.012

\title{
DETERMINANTS OF PRODUCTIVITY GROWTH IN DEVELOPING COUNTRIES: WHAT REALLY MATTERS?
}

\author{
Roman Moskalyk, Liana Moskalyk \\ Ivan Franko National University of Lviv, \\ 1, Universytetska Str., Lviv, Ukraine, 79000; tel. (032) 239-47-81, \\ e-mail: r_moskalyk@ukr.net,lianamoskalyk@yahoo.com
}

\begin{abstract}
The research questions are what really matters for productivity growth of developing countries; how productivity growth determinants contribute for certain developing countries groups. Our study covers a set of key productivity growth determinants and investigates the causal impact of the determinants on total factor productivity in our sample. For empirical testing we use panel data methods for 72 developing countries for 1991-2011 with fixed effects in combination with instrumental variable analysis.. Our main empirical results report that imports in GDP and more significantly imports from highly innovative countries in GDP, foreign R\&D activity spillovers, FDIs, use of foreign intellectual property rights, and institutional improvement stay key factors of productivity growth in developing countries while human capital and domestic R\&D activity have more ambiguously impact ${ }^{1}$.

Key words: productivity growth; developing countries; trade; international technology diffusion;
\end{abstract} total factor productivity, research and development; institutions.

\section{Introduction}

Both classic and new growth theories support the idea that productivity growth is the driving force of economic growth of a country. One of the current hot topics in economic literature is the role of different factors of productivity growth. A set of studies claims that productivity growth determinants differ among the developed and developing countries. Besides we argue that the value of productivity determinants may greatly differ also within the group of developing countries depending on their development levels. The divergence among the developing countries has only continued within the last decade. Therefore on a multinational level any universal policy approach for developing countries as a group does not likely meet the productivity growth challenges for these countries. The research questions are what really matters for productivity growth of the developing countries; and how productivity determinants are important for certain developing countries groups?

Our goal is to determine the key factors of productivity growth in the developing countries. We especially focus on the ways the technologies and knowledge diffuse in the developing countries from abroad. These are imports in GDP, foreign R\&D

\footnotetext{
${ }^{1}$ The article is based on the materials of research of Roman Moskalyk in the framework of Economics Education and Research Consortium, 2013-2014.
}

(C) Moskalyk Roman, Moskalyk Liana, 2014 
activity spillovers, human capital, foreign direct investments, use of foreign intellectual property rights, domestic R\&D activity, and institutional improvement. We investigate the causal impact of the key determinants on total factor productivity in our sample of 72 developing countries for the period of 1991-2011. For empirical testing we use panel data methods with fixed effects in combination with instrumental variable analysis for imports. We find out the key interactions between some determinants greater causing the productivity growth of developing countries.

We aim to test the importance of the productivity growth determinants for particular groups of developing countries depending on their income level to prove the idea that the developing countries are quite different and require particular policy application.

\section{Literature Review}

Theoretical growth studies suggest complex and different relationships between productivity growth and its determinants. The new growth theory supposes that "a country's openness to world trade improves domestic technology, and hence an open economy grows faster than a closed economy through its impact on technological enhancement" [1,p.229]. The theoretical foundations of the new growth theory are discussed in Romer [2] and Lucas [3], and further developed by Grossman and Helpman [4], and others. Taking into consideration the above approach we can substantiate the following sources of productivity growth.

Sources of productivity growth. Trade, R\&D, and R\&D spillovers are generally considered to be the important determinants for productivity growth according to the new growth theory and recent influential studies [5]. Danquah et all (2011) empirically finds that the most robust TFP growth determinants are trade openness and technological progress (i.e. innovation) [6]. Santacreu (2011) finds that the trade channel is of particular importance in developing countries, accounting for about three-fourths of their growth [7]. Moskalyk (2008, Appendix A) summarizes that namely imports are important for obtaining new knowledge effecting the productivity growth [8]. As for export's contribution to a country's productivity one can argue whether firms learn about foreign technology through exporting experience. The logic and the empirical evidence mostly say no. Moreover the issue of causal relationship between export and productivity is not clear [9].

Azomahou, Bity and Mbaye (2013) using country panel data over 1998-2008 for both developed and developing countries prove that $R \& D$ expenditure internally and from abroad impact positively the productivity growth [10]. Coe and Helpman (1995) initiated and other studies continued reporting the importance of domestic R\&D capital stock, North-South R\&D spillovers on the overall productivity growth of the South [11]. The literature summarizes that international technology can be transferred by market transactions and externalities. Keller (2004) stresses that most of them occur namely through externalities (spillovers) but good data on them do not exist [9]. In our research we try to capture at least some components of the externalities by 
employing North-South R\&D spillovers implementing the approach of Coe and Helpman (1995), as well as and international licensing/patenting by non-residents.

The theory suggests that the next source of productivity growth is internal innovations in a country. But the existing influential studies on the issue tend to employ this variable only for a sample of developed countries, arguing that the R\&D expenditures are negligible in the majority of developing countries and their domestic R\&D capital is assumed to be constant [12]. Moskalyk (2008) provides some empirical evidence that the domestic R\&D tend to be more important for developing countries' productivity recently, however the issue seems to be studied more explicitly [8]. We argue that the country's level of economic development might be the crucial point for the country to be able to use complicated technology successfully. The economic literature recognizes human capital as an important determinant of productivity growth. Human capital indicates the quality of the country's labour force that is to use the intermediate products, technology and other intellectual inputs effectively obtained through foreign trade and other channels of international technology diffusion. The higher quality of institutions can cause the growth of a country. However, the important challenge is to determine the proper institution indicator most directly influencing the productivity growth. We may suppose that different kinds of institutions may contribute better on a country's different levels of economic development.

Continuing discussion about FDIs as productivity growth determinant the recent studies report slight evidence for substantial FDI spillovers. It might be aggregation bias because of heterogeneity across sectors/firms, so some researchers claim that micro level study is more relevant [9]. Moreover MNE could disseminate technology to domestic firms or might pick up new technologies from host country. The questions for our study is how technologically intensive are FDIs in the developing countries? We argue that FDI in services may contain technological component. Some positive impact of FDI in services and services liberalization on productivity of manufacturing sector are reported by many influential studies $[13,14]$. In our study we suggest to use variable total FDI in GDP, since the statistical data of FDI in services for our developing countries samples for our broad time period are limited.

The empirical evidence is not unambiguous. A number of empirical studies were undertaken to examine the relationship between growth and trade, $R \& D$ activity, $R \& D$ spillovers, and other channels of international technology diffusion, but they often show controversial or not explicit results. Even if growth and trade are correlated across countries, but the mechanisms underlying this relationship are not well understood [7].

Reasons of the mixed results and outline for our research. In our opinion the first fundamental reason of the mixed empirics is not focusing on the central link between the channels of international technology diffusion and economic growth. As the new growth theory suggests total factor productivity becomes endogenous mainly to trade and R\&D investments. Therefore we are focusing on the central link between 
productivity and trade, $R \& D$ as well as other channels of international technology diffusion.

The second reason might be a difficulty of measuring productivity determinants. Many studies use various approaches to measure trade, human capital, $R \& D$, foreign R\&D activity spillovers, use of intellectual property rights, and institutions examining their effects on economic growth. We argue that some of the measures can suffer from measurement bias. We explicitly check the appropriate measurement approaches and apply those that identify technology intensive components.

The third reason is that some econometric models did not explicitly test causality and endogeneity. In our study we use panel data analysis with fixed effects transformation to eliminate country heterogeneity and apply instrumental variable methods to tackle with other econometrics problems, notably endogeneity, e.g. due to the omission of time-varying explanatory variable or simultaneity problem. We primarily look for proper time-varying instruments for our trade openness and R\&D variables. In the following Section we justify our instrumental variables in-depth.

The fourth reason is possible specification bias. The economic literature arguments that different channels of international technology diffusion (including trade, FDI, $\mathrm{R} \& \mathrm{D}$, foreign $\mathrm{R} \& \mathrm{D}$ activity spillovers, international licensing) as well as a set of domestic factors (internal innovations, human capital, and institutions) are important factors of productivity growth in a country. Similar as Coe and Helpman (1995), Coe, Helpman and Hoffmaister (2008) and others we put in the regression both variables imports in GDP and foreign R\&D activity spillovers (RDF). A rationale for including a variable of imports in GDP is to define the effect of pure trade channel on productivity growth, and a rationale of including foreign $R \& D$ activity variable is to define the diffusion effects of R\&D activity of developed countries on productivity growth of developing countries.

However some earlier studies tended to omit some of the factors because of data limitations at that time or other considerations. We argue that these determinants are key factors for the developing countries and time-varying statistical data are more available now. Moreover a particular group of developing countries depending on development level can benefit from a particular factor(s). The challenge is to adjust these specific factors and identify the role of each for productivity growth.

The fifth reason is too broad sample of countries with different levels of economic and technological development. We argue about significant distinction in technological level between developed and developing countries as well as among the group of developing countries, even more evidently in the recent decades. Not counting these differences in the broad samples can result unclear picture of which determinants really matter for the productivity of the sample. We may try to capture the effects of the productivity growth determinants for the certain groups of developing countries.

Thus we intend to find new proofs for the new growth theory and make causal explanations of productivity growth in developing countries paying attention to 
specific importance of productivity determinants in developing countries groups depending on their development level. Our paper contributes to the literature related to Coe, Helpman and Hoffmaister (2008) and other studies of the topic. First, we employ the broader range of productivity growth determinants as use of foreign intellectual property rights, overall FDI in GDP, domestic R\&D and institutions of the developing countries. Second, we investigate impact of total imports in GDP and imports from highly innovative countries in GDP and report the greater effect of the last on productivity growth. Third, we test a set of institution components to define which are more crucial for productivity growth of developing countries. It seems that trade freedom and freedom from corruption among others contribute greater to productivity growth. Forth, we argue that the value of productivity determinants may greatly differ also within developing countries since the divergence among developing countries has only continued in the last decades. Therefore we study the impact of productivity growth determinants for several groups of developing countries depending on their income level. The divergence among the developing countries has only continued within the last decade. The study of the issue is rather new aspect in the literature.

\section{Model Specification}

In our study we examine the causality of relationship between total factor productivity (TFP) and its key determinants for all developing countries for whom statistical data are available for the period of 1991-2011 (72 countries and 21 years). To tackle with possible endogeneity problems in estimating equations we use panel data methods with fixed effects in combination with instrumental variable analysis. Alternatively we discuss below the ability to employ of panel cointegration techniques.

The theoretical model is based on the new growth theory and in particular the approach of Coe, Helpman, and Hoffmaister (1997, 2008), Coe and Helpman (1995), Keller (2004), Lumenga-Neso, Olarreaga and Schiff (2005) [15] with some extensions. In particular we focus on the technological intensity of productivity growth sources. We add into analysis those indicators that can causally explain productivity growth in developing countries. We define TFP as logarithms of indices with 2005=1. We provide methodology of calculation of TFP and key determinants in Appendix A and descriptive statistics of our variables are presented in Appendix B. The basic and/or extended log-linear specifications are reflected in the equations that relate TFP of developing countries to the key determinants, in particular:

(1) Trade openness, measured as imports in GDP in logarithms, IMP, and alternatively imports from highly innovative countries in GDP in logarithms, IMP_HIC. We intend to test the effects of total imports comparing to imports from highly innovative countries on productivity growth.

(2) Foreign R\&D activity spillovers, $R D F$ (logarithms of indices, 2005=1, of import-weighted foreign R\&D capital stock of 22 innovative countries as in Coe and Helpman, 1995). 
(3) Human capital, HC (logarithms of indices, 2005=1, of primary school completion relative to the population of relevant age).

(4) Foreign direct investments in GDP in logarithms, FDI.

(5) Use of foreign intellectual property rights, IPR (logarithms of indices, 2005=1, of royalty and license fees payments abroad).

(6) Quality of institutions measured as Index of Economic Freedom (Heritage Foundation) in logarithms, $I$, and alternatively its disaggregated components property rights freedom $\left(I_{-} P R\right)$, trade freedom $\left(I_{-} T F\right)$, freedom from corruption $\left(I \_C O R\right)$, investment freedom $\left(I \_I F\right)$.

(7) Domestic R\&D activity, $R D D$ (logarithms of ratio of domestic R\&D expenditures to GDP).

(8-...) Interactions between imports and foreign R\&D activity spillovers and other productivity growth determinants.

$$
\begin{aligned}
& \log \mathrm{TFP}_{\mathrm{it}}=\mathrm{a}_{1} \log I M \mathrm{P}_{\mathrm{it}}+\mathrm{a}_{2} \operatorname{logRDF} \mathrm{it}_{\mathrm{it}}+\mathrm{a}_{3} \operatorname{logHC} \mathrm{it}_{\mathrm{it}}+\mathrm{a}_{4} \log \mathrm{FDI}_{\mathrm{it}}+\mathrm{a}_{5} \operatorname{logIRP} \mathrm{it}_{\mathrm{it}}+\mathrm{a}_{6} \log \mathrm{I}_{\mathrm{it}}+ \\
& +\mathrm{a}_{7} \log \mathrm{RDD} \mathrm{it}_{\mathrm{it}}+\mathrm{a}_{8} \log \mathrm{IMP} \mathrm{P}_{\mathrm{it}} \operatorname{logRDF} \mathrm{i}_{\mathrm{it}}+\mathrm{a}_{9} \log \mathrm{IMP}_{\mathrm{it}} \log \mathrm{I}_{\mathrm{it}}+\mathrm{a}_{10} \operatorname{logRDF_{\mathrm {it}}} \operatorname{logRDD} \mathrm{D}_{\mathrm{it}}+\ldots+\mathrm{c}_{\mathrm{i}}+\mathrm{u}_{\mathrm{it}}
\end{aligned}
$$

We consider that $I M P_{i t}$ can be endogenous, since higher productivity can affect higher import shares of a country $i$ while the other variables are assumed to be strictly exogenous. To model possible endogeneity we allow $I M P_{i t}$ to be contemporaneously correlated with $u_{i t}$. This correlation can be due to any of the three problems: omission of an important time-varying explanatory variable, measurement error in some elements of $I M P_{i t}$, or simultaneity between $T F P_{i t}$ and $I M P_{i t}$. We assume that equation (1) is the equation of interest. In a simultaneous equation model with panel data, equation (1) represents a single equation, but we must use appropriate instrumental variables (IVs).

Instrumental variables justification. In our research we employ some exogenous time-varying IVs that do not appear in equation (1) but that affect $I M P_{i t}$ as instruments (tested in Moskalyk, 2008 [8]):

1. Industry value added (constant 2005 US\$) in highly innovative countries (20 OECD states) weighted by the bilateral import shares of the developing country with each of 20 OECD countries, logarithm of index (year 2005=1), IVA variable. In terms of economic theory the growth of industry value added can increase supply for exports of the industrial products in the OECD country and demand for imports of the industrial products abroad, including in developing countries. Since the industry of the OECD countries creates highly technological products, the growth of its value added can be directly related to increase of the technologically intensive imports of the developing country. From the economic theory we cannot find any direct link between growth of industry value added in one country (the OECD country) and increase of TFP in other country (developing one). The growth of industry value added in the OECD country can influence the developing country's TFP only through the developing country's purchases (imports) and use of the industry products. Therefore 
Roman Moskalyk, Liana Moskalyk

ISSN 2078-4333. Вісник Львівського університету. Серія міжнародні відносини. 2014. Випуск 36. Частина 1

in the economic sense we may consider this IV as an appropriate one because the change in the instrument is directly related to the change in the technologically intensive imports of the developing country and is not related to changes in the developing country's TFP.

We employ the import weighted industry value added variable (IVA) with the oneyear lag as an instrument for the IMP variable. The lag of one year is expected to be the proper time span between production by innovative developed countries and imports by developing countries necessary for getting to know about the innovative countries' products, for negotiating export-import contracts and delivering. The econometric tests strongly support the idea of the one-year lag of weighted industry value added variable as an instrument for the IMP.

2. Other possibility, is to use lags of the variables as instruments. In our research we use one-year lag of the $I M P$ variable as instrument. The econometric tests support the hypotheses that these instruments are valid and strong (table 1).

To capture the determinants effects on productivity growth for different groups of developing countries we also employ the dummies for each countries groups for each determinant.

\section{Estimation Results}

We have received the empirical evidence of the impact of the key determinants on productivity growth in the developing countries. We find out that the productivity growth of developing countries mostly relies on major channels of international technology diffusion as well as on some internal factors. We employ basic specifications with a few main productivity growth determinants as in the style of Coe, Helpman and Hoffmaister $(1997,2008)$. We confirm that trade openness measured as imports in GDP $(I M P)$ and alternatively imports from highly innovative countries in GDP (IMP_HIC) positively affect the productivity growth. In fact imports from highly innovative countries contribute to productivity growth much greater than overall imports (table 1).

Table 1

The Basic and Extended Model Specifications (2SLS, fixed effects)

\begin{tabular}{|l|c|c|c|c|c|c|}
\hline & $(1)$ & $(2)$ & $(3)$ & $(4)$ & $(5)$ & $(6)$ \\
\hline & $T F P$ & $T F P$ & $T F P$ & $T F P$ & $T F P$ & $T F P$ \\
\hline \multirow{2}{*}{$I M P$} & 2 & 3 & 4 & 5 & 6 & 7 \\
& 0.017 & $0.081^{*}$ & & & & \\
\hline$I M P \_H I C$ & $(0.47)$ & $(1.82)$ & & & & \\
& & & $0.203^{* * *}$ & $0.194^{* * *}$ & 0.030 & 0.046 \\
& & & $(5.05)$ & & $(0.71)$ & $(0.61)$ \\
\hline RDF & $0.227^{* * *}$ & $0.109^{* * *}$ & $0.277^{* * *}$ & $0.259^{* * *}$ & $0.143^{* * *}$ & $0.328^{* * *}$ \\
& $(8.67)$ & $(3.29)$ & $(11.11)$ & & $(4.46)$ & $(7.98)$ \\
\hline$H C$ & -0.026 & 0.037 & 0.028 & 0.024 & 0.052 & 0.037 \\
& $(0.92)$ & $(1.15)$ & $(0.92)$ & & $(1.58)$ & $(0.47)$ \\
\hline$F D I$ & & 0.006 & & $0.011^{* *}$ & $0.010^{*}$ & 0.009 \\
& & $(1.01)$ & & & $(1.86)$ & $(1.18)$ \\
\hline
\end{tabular}


Roman Moskalyk, Liana Moskalyk

End of table 1

\begin{tabular}{|c|c|c|c|c|c|c|}
\hline 1 & 2 & 3 & 4 & 5 & 6 & 7 \\
\hline$I P R$ & & $\begin{array}{c}0.014 * * * \\
(4.04)\end{array}$ & & & $\begin{array}{c}0.014 * * * \\
(3.98)\end{array}$ & $\begin{array}{c}0.037 * * * \\
(7.12)\end{array}$ \\
\hline$I$ & & $\begin{array}{c}0.469 * * * \\
(7.55)\end{array}$ & & & $\begin{array}{c}0.455 * * * \\
(7.35) \\
\end{array}$ & $\begin{array}{c}0.384 * * * \\
(4.72)\end{array}$ \\
\hline$R D D$ & & & & & & $\begin{array}{l}-0.025 \\
(1.16) \\
\end{array}$ \\
\hline Observations & 950 & 691 & 950 & 928 & 691 & 364 \\
\hline $\begin{array}{l}\text { Number } \\
\text { Country }\end{array}$ & 68 & 65 & 68 & 68 & 65 & 45 \\
\hline $\begin{array}{l}\text { Underidentific } \\
\text { ation test } \\
\text { (Anderson } \\
\text { canon. corr. } \\
\text { LM statistic): }\end{array}$ & $\begin{array}{c}401.288 \\
\text { Chi-sq(2) } \\
\text { P-val = } \\
0.0000\end{array}$ & $\begin{array}{c}253.870 \\
\text { Chi-sq(2) P-val } \\
=0.0000\end{array}$ & $\begin{array}{c}450.634 \\
\text { Chi- } \\
\text { sq(2) P- } \\
\text { val = } \\
0.0000 \\
\end{array}$ & $\begin{array}{c}433.546 \\
\text { Chi- } \\
\text { sq(2) P- } \\
\text { val = } \\
0.0000\end{array}$ & $\begin{array}{c}337.762 \\
\text { Chi-sq(2) P- } \\
\text { val }=0.0000\end{array}$ & $\begin{array}{c}127.554 \\
\text { Chi-sq(2) } \\
\text { P-val = } \\
0.0000\end{array}$ \\
\hline $\begin{array}{l}\text { Weak } \\
\text { identification } \\
\text { test (Cragg- } \\
\text { Donald Wald } \\
\text { F statistic): }\end{array}$ & 366.468 & 211.143 & 458.610 & 434.610 & 362.676 & 103.605 \\
\hline $\begin{array}{l}\text { Sargan } \\
\text { statistic } \\
\text { (overidentific } \\
\text { ation test of } \\
\text { all } \\
\text { instruments): }\end{array}$ & $\begin{array}{c}0.700 \\
\text { Chi-sq(1) } \\
\text { P-val = } \\
0.4027\end{array}$ & $\begin{array}{c}0.006 \\
\text { Chi-sq(1) P- } \\
\text { val }=0.9366\end{array}$ & $\begin{array}{c}1.065 \\
\text { Chi- } \\
\text { sq(1) P- } \\
\text { val = } \\
0.3020\end{array}$ & $\begin{array}{c}2.375 \\
\text { Chi- } \\
\text { sq(1) P- } \\
\text { val = } \\
0.1233\end{array}$ & $\begin{array}{c}0.203 \\
\text { Chi-sq(1) P- } \\
\text { val }= \\
0.6522\end{array}$ & $\begin{array}{c}1.942 \\
\text { Chi-sq(1) } \\
\text { P-val = } \\
0.1634\end{array}$ \\
\hline
\end{tabular}

I. $\quad$ Instrumented: IMP and IMP_HIC accordingly. Excluded instruments: IVA justified above and one-lagged value of instrumented variable accordingly.

Absolute value of $\mathrm{z}$ statistics in parentheses, * significant at $10 \%$; ** significant at $5 \%$; *** significant at $1 \%$.

Source: calculated by the author using Stata module xtivreg2 developed by Schaffer and Stillman (2007) [16].

We can interpret it that imports from highly innovative countries deliver more technologies and knowledge to the economy of less innovative countries. Trade integration with highly innovative countries might be a priority policy for a developing country. It can be an argument for Ukraine's choice of integration with the EU. The issue may be a subject of the further research.

Our next productivity growth determinant - foreign R\&D activity spillovers $(R D F)$ shows even greater economic importance and statistical significance than imports from innovative countries. We can interpret it that innovations accumulated in foreign countries diffuse into developing countries via imports and largely increase productivity in developing countries. In other words the increase of R\&D activity in 
trading partner of a developing country can increase productivity growth of a developing country. We can observe the large and significant coefficients of $R D F$ in all specifications (table 1).

In addition to our basis (short) specification as in the Coe-Helpman-Hoffmaister style, we also employ extended specifications. We found that our productivity growth determinants as foreign direct investments $(F D I)$, use of foreign intellectual property rights $(I P R)$, and institutions $(I)$ can positively affect the productivity growth in developing economies, however the economic magnitude and statistical significance varies within estimations (table 1, specifications 4-6).

From the other side human capital $(H C)$ and domestic R\&D activity $(R D D)$, may have more ambiguous impact on productivity growth in our sample. The detailed study of these determinants is done for a certain groups of developing countries. Also we can state that our human capital and domestic R\&D activity variables have many omitted observations due to poor data for developing countries for our time period that may cause the results insufficiency. Besides we may suggest that the further research is required to test the alternative measures of human capital and domestic R\&D to shed light on this problem.

\section{Conclusions}

In our study we investigate the importance of a set of major determinants of productivity growth in developing countries. For a group of 72 developing countries for the period of 21 years (1991-2011) we estimate equations that relate developing countries' total factor productivity to the imports in GDP and alternatively imports from highly innovative countries in GDP, foreign R\&D activity spillovers from highly innovative countries, human capital, foreign direct investments in GDP, use of foreign intellectual property right, domestic R\&D activity, as well as institutions. The relationships are examined using panel data methods with fixed effects in combination with instrumental variable analysis. We use the time-varying instruments for our imports variables to deal with endogeneity bias in estimating equation that are as follows: 1) one-year lagged industry value added in highly innovative industrial countries weighted by the bilateral import shares of the developing country with each of these countries; 2) one-year lag of our imports variable. We found some proofs that the instruments are acceptance from theoretical and econometric point of view.

Our results report the major sources of productivity growth in the developing countries remain the channels of international technology diffusion. We prove that imports and much greater imports from highly innovative countries together with foreign R\&D activity spillovers, FDIs, use of foreign intellectual property rights, and institutional improvements stay the major determinates of productivity growth in developing countries. These findings are consistent with the new growth theory and some recent empirical studies. Also domestic R\&D activity and human capital can positively increase TFP in developing countries as the theory says; however these determinants coefficients are rather low and not significant in some specifications. 
Human capital and domestic R\&D seem to be more important interacted with imports and foreign $R \& D$ activity spillovers.

\section{Bibliography}

1. Jin, Jang C. Can Openness Be an Engine of Sustained High Growth Rates and Inflation? Evidence from Japan and Korea/Jin, Jang C.// International Review of Economics and Finance.- 2006.- № 15(2).- P. 228-240.

2. Romer, Paul M. "Increasing Returns and Long Run Growth / Romer, Paul M. //Journal of Political Economy.-1986.- № 94.- P. 1002-1037.

3. Lucas, Robert J. On the Mechanics of Economic Development / Lucas, Robert J.// Journal of Monetary Economics.- 1988.- № 22(1).- P. 3-42.

4. Grossman, Gene M. and Helpman, Elhanan. Comparative Advantage and Long-run Growth/ Grossman, Gene M. and Helpman, Elhanan // American Economic Review.- 1990. - № 80.- P. 796-815.

5. Coe, David T., Helpman, Elhanan and Hoffmaister, Alexander W. International R\&D Spillovers and Institutions/ Coe, David T.; Helpman, Elhanan and Hoffmaister, Alexander W.// NBER Working Paper No.14069, NBER, Cambridge, MA, 2008.

6. Danquah, Michael; Moral-Benito, Enrique and Ouattara, Bazoumana. "TFP Growth And Its Determinants: Nonparametrics And Model Averaging". Madrid, 2011, The Working Paper Series. - Available at : - http://Ssrn.Com/Abstract=1803371.

7. Santacreu, Ana Maria. "Innovation, Diffusion, and Trade: Theory and Measurement". INSEAD Working Paper No. 2011/127/EPS - Economics and Political Science, December 12, 2011. - Available at: http://papers.ssrn.com/sol3/papers.cfm?abstract_id=1634777.

8. Moskalyk, Roman. "Impact of Trade Openness and Technology Transfers on Growth: Panel Data Investigation for Developing Countries". - 2008. - 27 p. Available at: -http://papers.ssrn.com/sol3/papers.cfm?abstract_id $=1145188$.

9. Keller, Wolfgang. International Technology Diffusion / Keller, Wolfgang // Journal of Economic Literature. - 2004. - XLII. - P. 752-782.

10. Azomahou, Théophile T.; Bity Diene and Mbaye Diene. "Nonlinearities in Productivity Growth: A Semi-Parametric Panel Analysis". Structural Change and Economic Dynamics. - 2013. - № 24. - P. 45-75.

11. Coe, David T. and Helpman, Elhanan. International R\&D Spillovers/ Coe, David T. and Helpman, Elhanan // European Economic Review. May - 1995. -№ 39(5).- P. 859-887.

12. Coe, David T., Helpman, Elhanan and Hoffmaister, Alexander W. NorthSouth R\&D Spillovers / Coe, David T., Helpman, Elhanan and Hoffmaister, Alexander W.// Economic Journal. - 1997. - № 107.- P. 134-149. 
Roman Moskalyk, Liana Moskalyk

ISSN 2078-4333. Вісник Львівського університету. Серія міжнародні відносини. 2014. Випуск 36. Частина 1 13

13. Tarr, David G. "Putting Services and Oreign Direct Investment with Endogenous Productivity Effects in Computable General Equilibrium Models / Tarr, David G. // Policy Research Working Paper Series 6012. The World Bank, 2012.

14. Shepotylo, Oleksandr and Vakitov, Volodymyr. "Impact of Services Liberalization on Productivity of Manufacturing Firms: Evidence from the Ukrainian Firm-Level Data," World Bank Policy and Research Working Paper Number 5944, January 2012.

15. Lumenga-Neso, Olivier; Olarreaga, Marcelo and Schiff, Maurice. On 'Indirect' Trade-Related R\&D Spillovers / Lumenga-Neso, Olivier; Olarreaga, Marcelo and Schiff, Maurice // European Economic Review, Elsevier, 2005. - № 49(7).- P. 1785-1798.

16. Schaffer, Mark E. and Stillman, Steven. "xtivreg2: Stata module to perform extended IV/2SLS, GMM and AC/HAC, LIML and k-class regression for panel data models." 2007. <http://ideas.repec.org/c/boc/bocode/s456501.html $>$.

Стаття надійшла до редколегії 01.11.2014. Прийнята до друку 01.12.2014.

\section{ДЕТЕРМІНАНТИ ЗРОСТАННЯ ПРОДУКТИВНОСТІВ КРАЇНАХ, ЩО РОЗВИВАЮТЬСЯ: ЩО НАСПРАВДІ ВАЖЛИВО}

\section{Роман Москалик, Ліана Москалик}

Львівський національний університет імені Івана Франка, вул. Університетська, 1, м. Львів, Украӥна, 79000; тел. (032) 239-47-81, e-mail: r_moskalyk@ukr.net, lianamoskalyk@yahoo.com

\footnotetext{
Розглянуто детермінанти зростання продуктивності країн, що розвиваються. Дослідження охоплює ряд ключових чинників зростання продуктивності і досліджує їхній причиннонаслідковий вплив на сукупну продуктивність факторів у нашій вибірці країн. Для емпіричного дослідження використано методи аналізу панельних даних (1991-2011рр.) для 72-х країн, що розвиваються, у поєднанні з методом фіксованих ефектів та аналізу інструментальних змінних. Основні емпіричні результати засвідчують, що імпорт i, зокрема, імпорт 3 інноваційних країн, зовнішні ефекти від іноземної науково-дослідної діяльності, прямі іноземні інвестиції, використання іноземних прав інтелектуальної власності, а також інституційні поліпшення залишаються ключовими факторами зростання продуктивності в країнах, що розвиваються
} 
Водночас людський капітал і внутрішня науково-дослідна діяльність країн, що розвиваються, мають більш неоднозначний вплив на їхню продуктивність.

Ключові слова: зростання продуктивності; країни, що розвиваються; торгівля; міжнародне поширення технологій; сукупна продуктивність факторів, досліджень і розробки; інституції.

\section{ДЕТЕРМИНАНТЫ РОСТА ПРОИЗВОДИТЕЛЬНОСТИ В РАЗВИВАЮЩИХСЯ СТРАНАХ: ЧТО ДЕЙСТВИТЕЛЬНО ВАЖНО?}

\section{Роман Москалык, Лиана Москалык}

Львовский национальный университет имени Ивана Франко, ул. Университетская, 1, г. Львов, Украина, 79000; тел. (032) 239-47-81, e-mail:r_moskalyk@ukr.net,lianamoskalyk@yahoo.com

Рассматрены детерминанты роста производительности развивающихся стран. Исследование охватывает ряд ключевых факторов роста производительности и исследует их причинноследственное воздействие на совокупную производительность факторов в нашей выборке стран. Для эмпирического исследования использованы методы анализа панельных данных (1991-2011 гг.) для 72-х развивающихся стран в сочетании с методом фиксированных эффектов и анализа инструментальных переменных. Основные эмпирические результаты свидетельствуют, что импорт, в особенности импорт из инновационных стран, внешние эффекты от иностранной научно-исследовательской деятельности, прямые иностранные инвестиции, использование иностранных прав интеллектуальной собственности, а также институциональные улучшения остаются ключевыми факторами роста производительности в развивающихся странах. В то же время человеческий капитал и внутренняя научно-исследовательская деятельность развивающихся стран имеют более неоднозначное влияние на их производительность.

Ключевые слова: рост производительности; развивающиеся страны; торговля; международное распространение технологий; совокупная производительность факторов, исследований и разработки; институции. 